Historic, Archive Document

Do not assume content reflects current scientific knowledge, policies, or practices. 



\section{PHENOLOGY AND OTHER FEATURES OF THE}

FLOWERING OF PINES, WITH SPECIAL REFERENCE

TO PINUS MONTICOLA DOUGL.

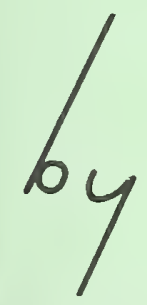

R. T. BINGHAM AND A. E. SQUILLACE FORESTERS

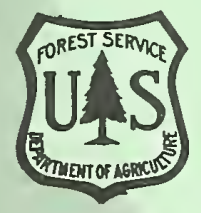

NORTHERN REGION

$$
\text { AND }
$$

INTERMOUNTAIN FOREST AND RANGE EXPERIMENT STATION FOREST SERVICE

U. S. DEPARTMENT OF AGRICULTURE

OGDEN, UTAH 


\section{United States}

Department of

Agriculture

解.

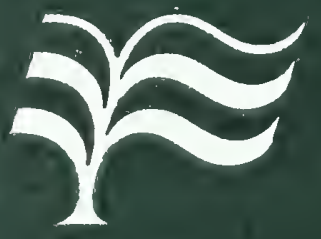

National Agricultural LIBRARY

Advancing Access to Global Information for Agriculture 


\title{
PHENOLOGY AND OTHER FEATURES OF THE FLOWERING OF PINES, WITH SPECIAL REFERENCE TO PINUS MONTICOLA DOUGL.
}

\section{By}

\author{
R. T. Bingham and A. E. Squillace \\ Foresters
}

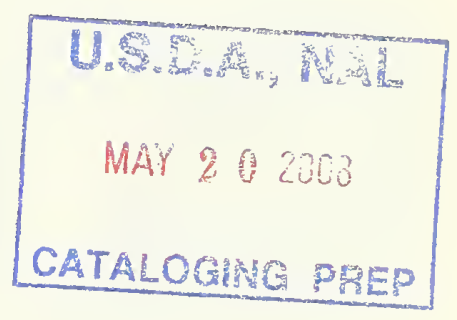

\author{
NORTHERN REGION \\ and \\ INTERMOUNTAIN FOREST AND RANGE EXPERIMENT STATION \\ Forest Service \\ U. S. Department of Agriculture \\ Ogden, Utah
}





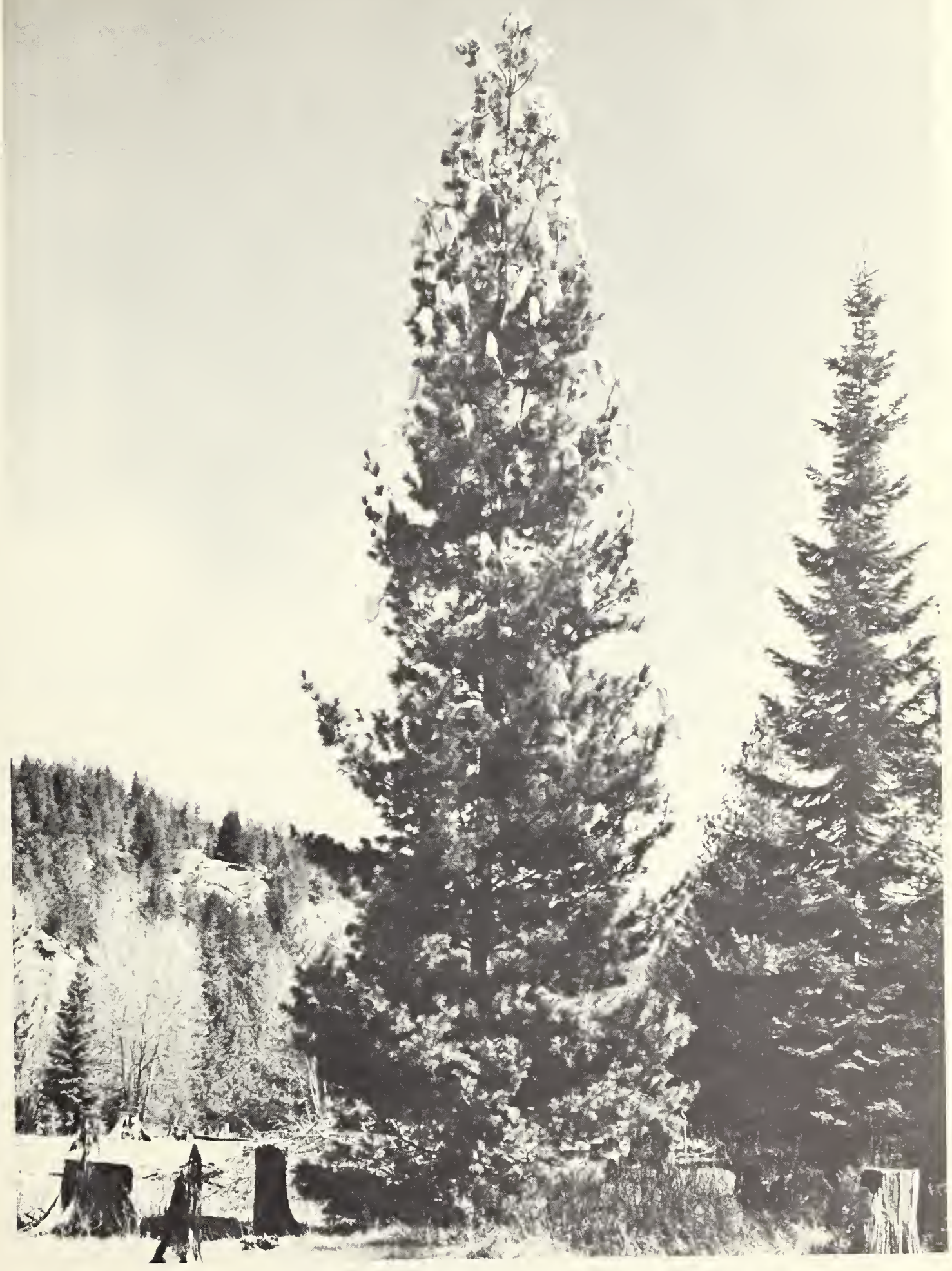

Rust-resistant tree No. 19. bagged with cloth sacis to protect controlled pollinated cones from insects and squirrels. 

CONTENTS

Page

Introduction . . . . . . . . . . . . . . . . . . . . . . . . . . . 1

Review of literature . . . . . . . . . . . . . . . . . . . 2

Materials and methods . . . . . . . . . . . . . . . . 6

Results and discussion . . . . . . . . . . . . . . . . . . . 7

Time and duration of the flowering period . . . . . . . . . . 7

Consistency in sequence of flowering . . . . . . . . . . . . . 14

Year-to-year variation in the time of flowering . . . . . . . . 15

Timing and overlap of periods of staminate and ovulate flowering . . . . . . . . . . . . . . . 17

Conclusions . . . . . . . . . . . . . . . . . . . . . . . 20

Summary . . . . . . . . . . . . . . . . . . . . . . 21

Literature cited . . . . . . . . . . . . . . . . . . 22 

PHENOLOGY AND OTHER FEATURES OF THE FLOWERING OF PINES, WITH SPECIAL REFERENCE TO PINUS MONTICOLA DOUGL.

R. T. Bingham and A. E. Squillace $-1 /$

\section{INTRODUCTION}

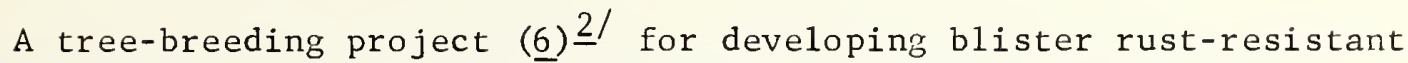
(Cronartium ribicola Fischer) and otherwise improved western white pine (Pinus monticola Doug1.) planting stock was begun in the Inland Empire region in 1950. From 1950 through 1955 controlled pollinations were made between as many pairs of rust-resistant selections as possible. Limited ovulate flowering of the young trees used controlled the number of crosses made. In the routine controlled pollination work a fund of information concerning flowering habits of 45 young, rust-resistant white pines was accumulated. This evidence is assembled to increase the general knowledge of flowering in $\underline{P}$. monticola and for its direct usefulness in planning future controlled polīination work and seed orchard studies.

P. monticola is among those pines considered as requiring 2 years to mature seed. Actually, three consecutive growing seasons are involved since floral primordia are differentiated in the growing season prior to their appearance and recognition as full-fledged micro- or megasporangiate strobili. The maturing male and young female strobili, hereafter called staminate and ovulate "flowers," first become visible in the bud stage in June of the year following initiation of primordia. They emerge from the bud scales, the staminate flowers shedding pollen and the ovulate flowers becoming receptive to pollination more or less simultaneously, in the period between late June and early July.

Ordinarily the period of anthesis (pollen release) is considered to continue from the time of natural dehiscence of the first few normal microsporangia until the dehiscence of microsporangia in the male flowers of a given tree or stand is complete. The receptive period in ovulate flowers is considered to be the period during which the flower or "conelet" scales are open so that pollen may be air-borne to the micropylar openings of the egg sacs found at the base of the scales. In this respect, ovulate flower stages "partly open" (with scales beginning to open by reflexing downward from a position along the erect axis of the conelet) to "partly closed" (with the outer tips of the conelet scales beginning to swell together and limit pollen access) are considered by the majority of pine-breeders to span the complete period of receptivity.

1/ Bingham is Forester (Silviculture), Division of Blister Rust Contro1, Region 1, U. S. Forest Service, and Squillace is Forester (Silviculture), Intermountain Forest and Range Experiment Station, U. S. Forest Service, Spokane, Washington.

2/ Numbers in parentheses refer to LITERATURE CITED page 22. 
Distinct maxima in pollen release and ovulate flower receptivity occur within stands--the bulk of the microsporangia dehiscing within a few days and the bulk of the ovulate flowers reaching and remaining in stage "flowers maximum" (scales completely reflexed and at right angles to conelet axis allowing maximum pollen access) within a similar period. Once pollination has been effected, the male flowers die and the closed but still erect young ovulate cones continue to enlarge to an over-all length of 1 to $1 \frac{1}{2}$ inches, in which stage they overwinter. In the late spring or early summer of the next (third) growing season the pollen tube completes the yearlong process of penetrating the wall of the egg sac, fertilization takes place, and the young cone begins to enlarge rapidly, turning from an erect to a pendulous position. By mid-September of the same season the cones open and shed mature seed.

The thumbnail life history above is adequate for understanding of the results and discussion that follow. If the reader desires a more complete understanding of the processes involved, the following publications are recommended: (1) concerning the general appearance of various flowering stages-- $(38,45,10,53,1$, and 15); (2) concerning details of the mechanism of pollination in Pinus-- $(\underline{13})$; and (3) concerning embryology of Pinus-$(\underline{18})$.

\section{REVIEW OF LITERATURE}

Phenology, a contraction of the word phenomenology, or the branch of applied meteorology concerned with the influences of climate on the annual phenomena of plant and animal life, is by no means a young science. It probably dates from before 1750 when early botanists, Linneaus included, proposed the systematic recording of the time of appearance of leaves, flowers, and fruits in plants. The application of phenology to forestry has been summed up in two publications by Huberman (20 and $\underline{21}$ ).

The authors soon realized the hopelessness of completely reviewing even that part of the phenological literature concerned only with forest trees. Early observers lacked uniform criteria for describing annual phenomena and varied in their skill in describing and recognizing floral stages. These factors as well as the bulk and inaccessibility of the older literature caused the writers to restrict their survey mainly to more recent publications on floral phenology of conifers.

In addition to these publications, several important references on general plant phenology should be mentioned. Hopkins' (19) exposition on relationships of plants and climate and his experimental evidence associating the "bioclimatic" character of a local area with the dates of periodic events in plants, and indicating the use of periodic events in plants for determining sowing or harvesting dates, have had wide practical application. His "Bioclimatic Law" that in the United States there is an average 4 days' lag in the occurrence of annual events in plants for each $1^{\circ}$ latitude northward, for each $5^{\circ}$ longitude eastward, and for each 400 feet increase in 
elevation is often used and quoted. Garner's (17) work on photoperiodism in respect to initiation of the flowering period showed that duration of light also influences the onset of flowering, a conclusion strengthened by the more recent work of Anderson and Hubricht (4). Thus photoperiodic requirements might be expected to have an important role in floral phenology, especially among exotic plants transplanted from one photoperiodic regime to another.

Among the more comprehensive early American studies that focused attention upon cumulative effects of late winter and spring temperatures in controlling time of flowering were the temperature summations of Blendel (7). Blendel showed that different species require different amounts of heat to perform various physiological functions, including flowering. His summations of positive average daily temperatures between January and May showed that temperature was the principal determinant of flowering time and that approximately the same number of heat units was required to induce the onset of flowering in the same species in either an "early" or a "late" year. Osterwalder (34) presented conclusive evidence of relation of early spring temperature summation to time of blossoming in fruit trees. Lindsey and Newman (25) outlined recent refinements in this method leading to much more sensitive heat summation appraisals.

Notable among phenological treatises dealing with flowering dates of American plants at a given locality were the 45-year Ohio data reported by Smith (44), the 20-year Manitoba data reported by Criddle (9), and the 17to 30-year data presented by Lindsey and Newman (25). Among the more important contributions concerning phenology of American deciduous trees are included observations by Lamb (22) in the eastern United States, by Wyman (52) at the Arnold Arboretum, Massachusetts, by Mehan (27) at the E11is College Arboretum in eastern Pennsylvania, and by Silker (42) in southeast Texas.

Also worthy of special mention is the paper by Stout ( $\underline{46}$ ) defining the various forms of dichogamy (maturation of male and female flowers at different times) associated with infertility in plants with special reference to American nut trees of the Betulaceae, Fagaceae, and Juglandaceae. This and other work concerning phenologically induced self- or crossinfertility in nut trees is covered later in the discussion of similar phenomena in $\underline{\mathrm{P}}$. monticola.

Concerning the principal field of literature covered--phenology of pine flowering--it appeared that the best way to review and present the literature in understandable form was by tabular sumary. Table 1 facilitates comparisons between individual trees and stands both within and between species, by species, authority, locality, and period of observation. Included are observations on duration of flowering in a given year, on year-to-year variation in time of flowering and associated climatic factors, on consistency of flowering time, and on flowering habit. The noteworthy features of conifer floristics brought out by the table are as follows: 
Table 1.--Review of the 1iterature on the phenology of ovulate and staminate flowering in pines

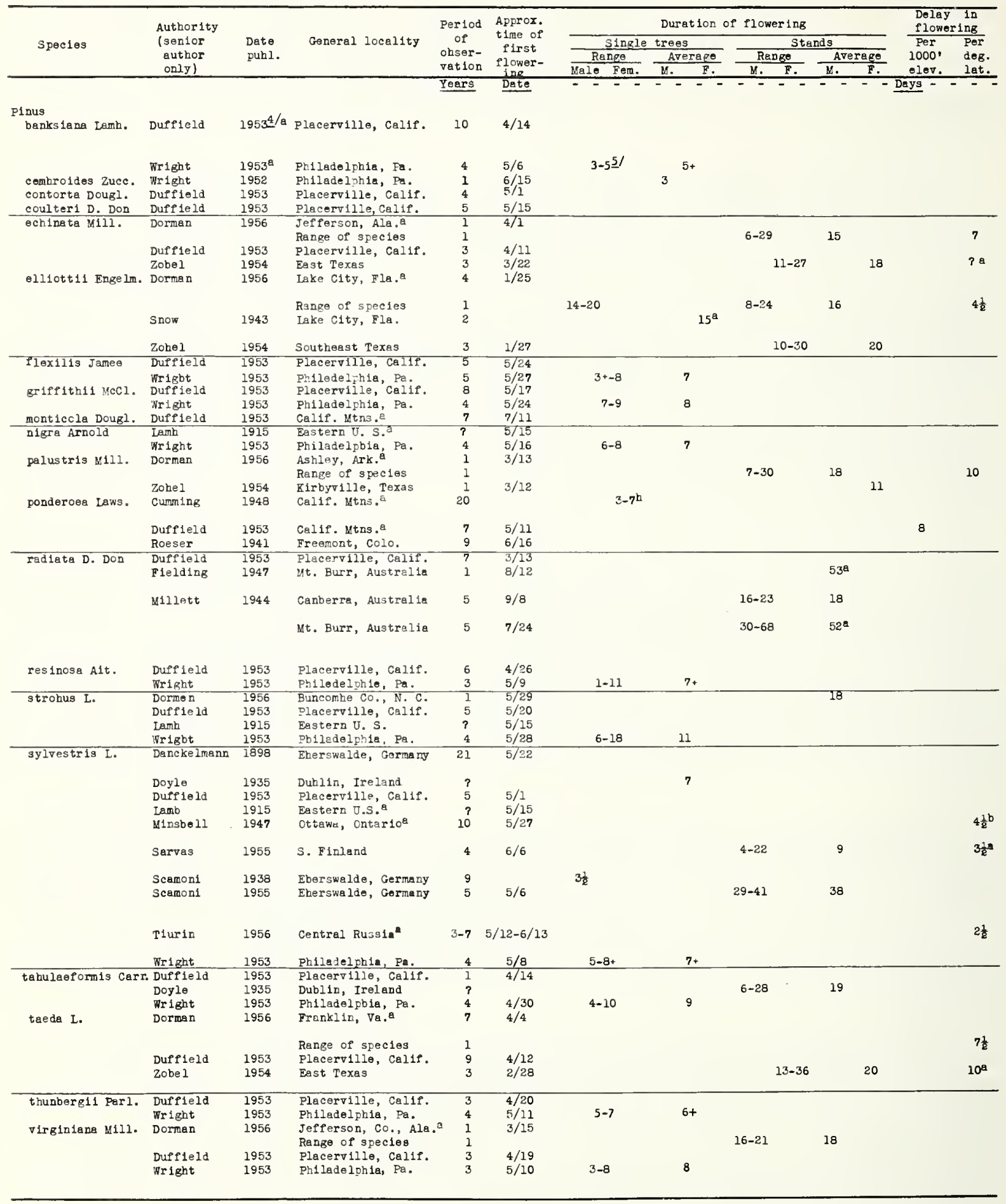

1/ Other factors found associated with yearly variation in flowering were $\operatorname{ar}$ temperature $(\mathrm{T})$, rain (R), relative humidity (H), and evaporation rate $(E)$.

2) Excluding obvious elevational or latituciral ctituctis, flowerisg was found consistently early or late among individual trees of the same species in the same locality (A), among stands of the same species in different localities (B), or among stands of different species in the same locality (C). 


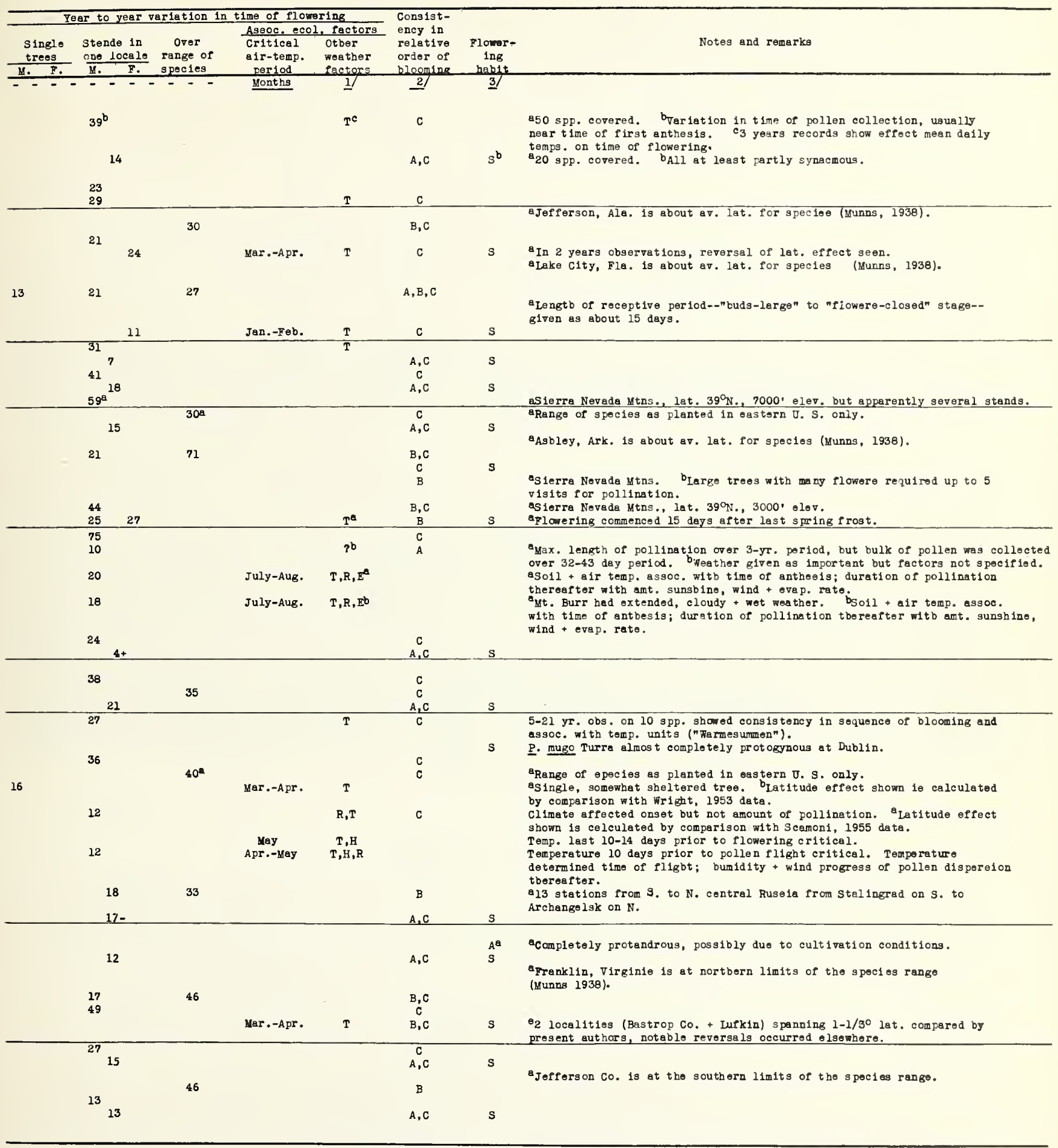

3/ Protandrous (male first) habit (A), protogynous (female first) hablt (B), synacmous (simultaneous flowering) habit (S).

4/ Small letters indicate that a note with corresponding letter will

be found in the notes and remarks column.

5/ Data centered between columns denotes that authority did not distingulsh between staminate and ovulate flowering periods. 
(1) The duration of staminate and ovulate flowering in individual pine trees is remarkably uniform both within and between species, averaging about a week in length, with a maximum duration of about 2 weeks.

(2) Flowering in stands of one species is sometimes of considerable duration, staminate flowering extending over a period of one-half to 10

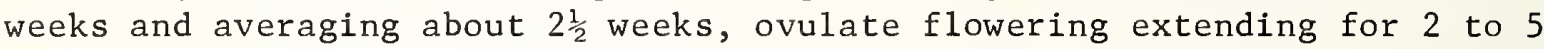
weeks and averaging about 3 weeks.

(3) For each degree latitude northward, most species exhibit a delay in flowering time averaging about 5 days. Thus in the United States most pines except the southern pines have values quite close to Hopkins' (19) mean of 4 days per degree of latitude.

(4) The large variation (4 to 75 days) in year-to-year flowering time of stands at the same locality depends partly on the number of years included in the observation period. "Early" blooming trees like Pinus radiata appear to be subject to the greatest variation in time of flowering.

(5) Temperature is a potent factor determining onset of flowering in a given year.

(6) A number of Pinus species exhibit consistency in respect to the "earliness" or "lateness" of flowering in individual trees. Consistency in the relative order of flowering of different species at the same locality is frequently noted.

(7) Very few clear-cut cases of complete dichogamy are reported for pines. Either partial or complete protandry or protogyny is evident in a few species. The majority, however, are either synacmous or have overlapping male and female flowering periods that should eliminate dichogamy as the major cause of self- or cross-incompatibility.

\section{MATERIALS AND METHODS}

The numbers of trees employed and the seasons involved in the phenological and flowering study of western white pine are outlined in table 2 . The over-all basis ( 45 trees) is fairly sound, but the locality (2 to 15 trees) or seasonal bases ( 7 to 41 trees, 6 seasons of observation) are less strong. Phenological observations were made on each individual tree that flowered during the years shown, with particular attention to the start, maxima, and end of staminate and ovulate flowering. The useful form, figure 1 , slightly modified from the original developed by the Institute of Forest Genetics, Placerville, California, was used in recording phenological observations by individual trees. Notes on dichogamy, position of male and female flowers, or on other features of flowering were appended. To aid in interpreting the data the starting, maxima, and ending dates of staminate and ovulate flowering were plotted by locality and observation year, as in figure 2. To facilitate comparison, dates were numbered consecutively with June 1 as day number 1 . 
Table 2.--Basis of the observations, numbers of trees observed, by localities and seasons

\begin{tabular}{|c|c|c|c|c|c|c|c|c|c|}
\hline \multirow{2}{*}{ Locality } & \multirow{2}{*}{$\begin{array}{c}\text { Eleva- } \\
\text { tion }\end{array}$} & \multirow{2}{*}{$\begin{array}{l}\text { Lati- } \\
\text { tude }\end{array}$} & \multicolumn{7}{|c|}{ Year of observations } \\
\hline & & & 1950 & 1951 & 1952 & 1953 & 1954 & 1955 & Total \\
\hline & Feet & ON. & \multicolumn{7}{|c|}{ Number of trees } \\
\hline Soldier Creek & 2,700 & $47^{\circ} 10^{\prime}$ & & & 2 & 2 & & & 2 \\
\hline Crystal Creek & 2,850 & $47^{\circ} 00^{\prime}$ & 14 & 8 & 13 & 15 & 5 & 6 & 15 \\
\hline Middle Fork St. & & & & & & & & & \\
\hline Maries River & 2,900 & $47^{\circ} 00^{\prime}$ & 4 & & 4 & 2 & & & 4 \\
\hline Gold Center & 2,950 & $47^{\circ} 00^{\prime}$ & 6 & 1 & 7 & 6 & 1 & & 8 \\
\hline Lower E1k Creek & 3,000 & $46^{\circ} 4^{\prime}$ & & 2 & 3 & 3 & 1 & 2 & 3 \\
\hline Emerald Creek & 3,000 & $46^{\circ} 58^{\prime}$ & 1 & & & 3 & & & 3 \\
\hline Upper Elk Creek & 3,300 & $46^{\circ} 52^{\prime}$ & & & 2 & 5 & & & 5 \\
\hline White Rock & 5,000 & $47^{\circ} 00^{\prime}$ & 1 & 2 & 5 & 5 & & & 5 \\
\hline Totals & & & 26 & 13 & 36 & 41 & 7 & 8 & 45 \\
\hline
\end{tabular}

\section{REjULT' AND DISCUSSION}

\section{Time and Duration of Flowering Period}

Among the $45 \mathrm{P}$. monticola trees observed over the period 1950 to 1955 , average date of anthesis at low elevations (2,700 to 3,300 feet) was June 27, at high elevations (5,000 feet) July 8. In the average year first receptive flowers at low elevations appeared June 29; at high elevations, July 7. Earliest pollen flight observed in the 6 years was June 10, 1952; 1atest, July 12; earliest receptive ovulate flowers June 10; latest, July 14.

Tables 3 and 4 sum up many features of staminate and ovulate flowering in western white pine as observed in this study. In respect to the duration of flowering in individual trees, the shortest and longest periods of pollen sheiling were observed to be 4 and 14 days, respectively; of ovulate flower receptivity 4 and 25 days, respectively. Stands within the 8 localities studied had average pollination periods ranging from 6 to 12 days (grand average 8.5 days based on 45 different trees), and average periods of ovulate flower receptivity ranging from 4 to 13 days (grand average 9.5 days based on 34 different trees). The duration of flowering in $\underline{P}$. monticola individuals and stands is quite similar to that of many other pines, as shown in table 1 .

Another interesting fact related to duration of flowering in western white pine brought out by figure 2 was the prolonged period of ovulate flowering in the most fruitful individuals. Trees number 19 and 20 (among the heaviest fruiters) show the prolonged ovulate flowering period. Notable exceptions to the generalization are tree 27, a light fruiter with a prolonged ovulate flowering period, and tree 58, a heavy fruiter with a relatively 


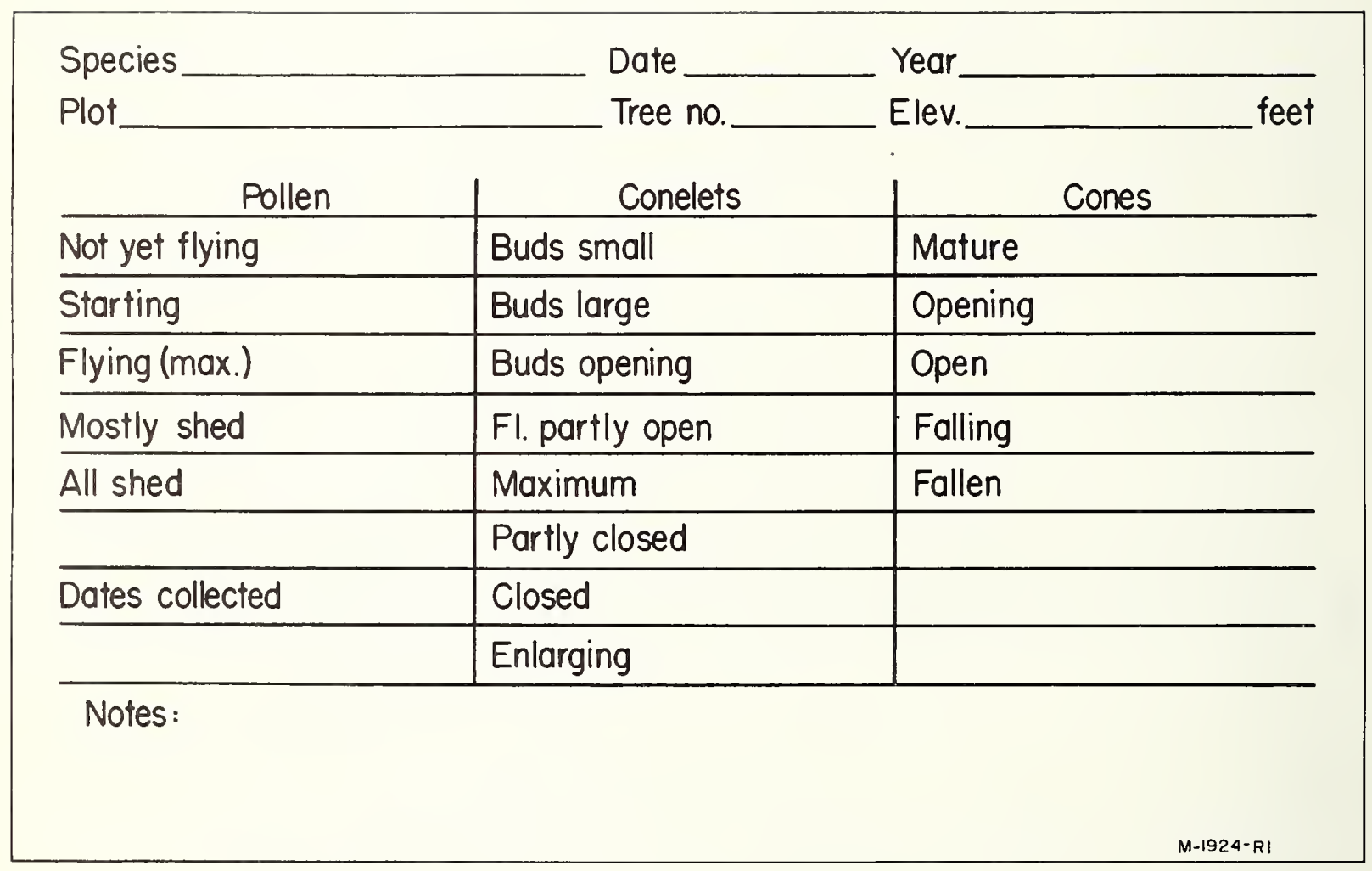

Figure 1.--Modified Institute of Forest Genetics form used for recording phenological observations. 


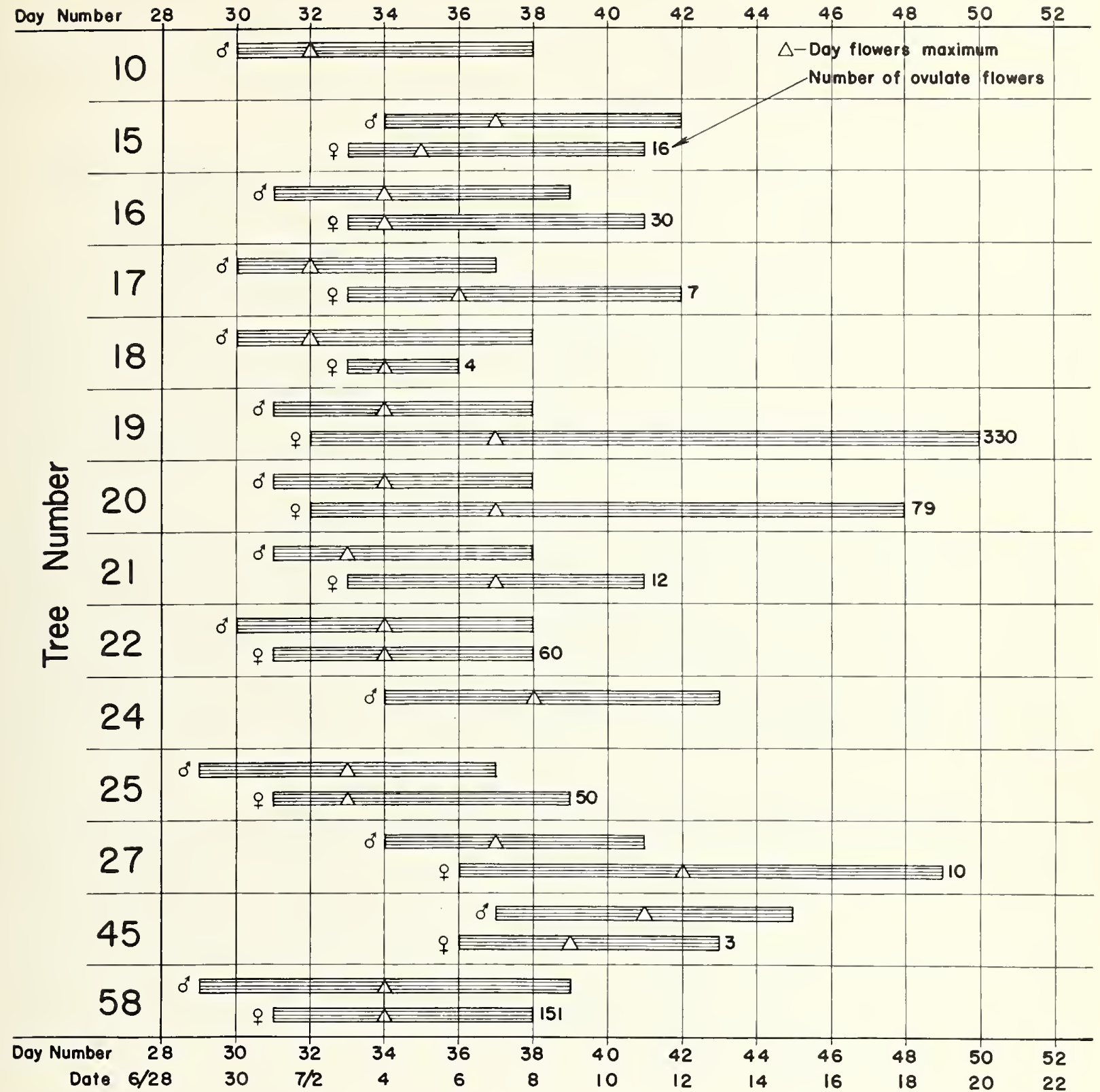

Figure 2.--Duration and maxima of ovulate and staminate flowering, Crystal Creek trees, year 1950 . 
short ovulate flowering period. Of the three most fruitful trees, numbers 19,20 , and 58, the period of ovulate flower receptivity was longer than average in selections 19 and 20. Both trees bore large numbers of ovulate flowers, many of them on inner and lower branches or in portions of the crown not exposed to direct sunlight. The sheltered flowers developed slowly and prolonged the flowering season.

Sčepotjev (40) noted the almost identical phenomenon in Juglans regia L. where he found flower ripening on the inner vs. the outer branches differing by as much as 4 to 10 days, thus extending the flowering season. Orr-Ewing (33) found prolongation of the flowering season in Pseudotsuga menziesii (Mirb.) Franco due to late ripening of the flowers on lower and northerly parts of the crown. Lengthening of the flowering season caused by successive ripening of ovulate flowers has been noted specifically for Pinus sylvestris (13), for $\underline{P}$. ponderosa $(10)$, for the four principal southern pines in fiast Texas (53), for Larix spp. (24), and for Picea abies (51). Sarvas (37) pointed out that in conifers and birches in southern Finland the years of most prolonged pollen dissemination were the years of most abundant pollen production.

Elevation and latitude, as they affect mean temperature, also affect the onset and duration of flowering as noted for many pines (table 1). Considering elevation, its effect on $\underline{P}$. monticola was best demonstrated in this study by comparing flowering at the one high-elevation locality (White Rock, 5,000 feet) with that at the other seven low-or medium-elevation localities $(2,700$ to 3,300 feet). Tables 3 and 4 show that during 4 years when observations were made at White Rock, staminate flowering was later on the average of 11 days, ovulate flowering 9 days, or about 5 days later per 1,000 feet increase in elevation.

Elevation had another effect on flowering of $\underline{P}$. monticola. Although year-to-year climatic variation had little, if any, effect on duration of flowering in individual trees except possibly at the higher elevations, the difference in time of onset of flowering in early vs. late years was much less at high- than at low-elevation localities (figure 3). The flowering seasons plotted in figure 3 were the earliest (1952) and the latest (1953) encountered in the 6-year study. At Gold Center, the low-elevation locality nearest White Rock, the difference between average dates of maximum flowering in the 2 years was approximately 15 days, while at White Rock (only 4 miles east but 2,050 feet higher) it was 8 days.

Wright (51) commented on a related phenomenon concerning telescoping of the over-all or all-species flowering season during later than average years at Philadelphia and at Ottawa (as reported by Minshal1 (29)). Ottawa lying some $5 \frac{1}{2} 0$ latitude to the north of Philadelphia had a later flowering season every year, but the effect of the later-than-average individual year caused more compression of the over-all season at Ottawa than at Philadelphia. In other words, duration of the flowering season of several species telescoped in cold, late springs, more so at colder than at warmer latitudes. Similarly,

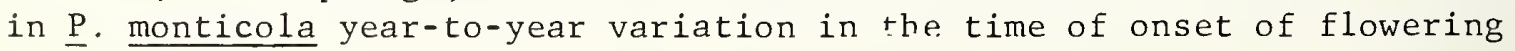




\begin{tabular}{|c|}
\hline 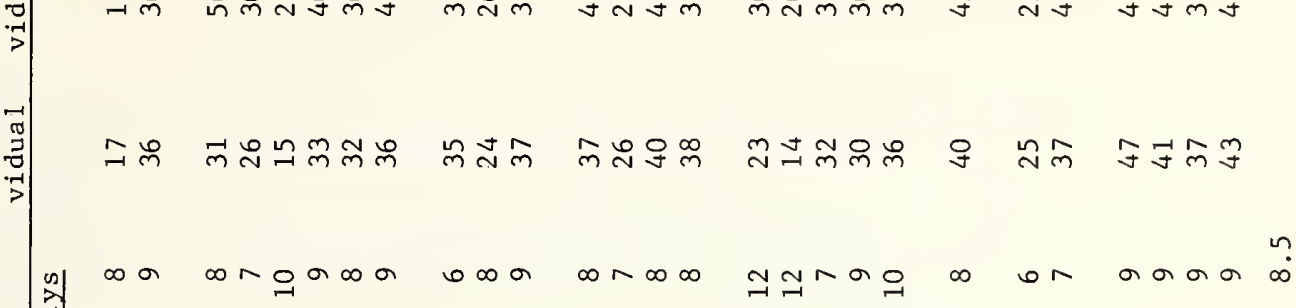 \\
\hline 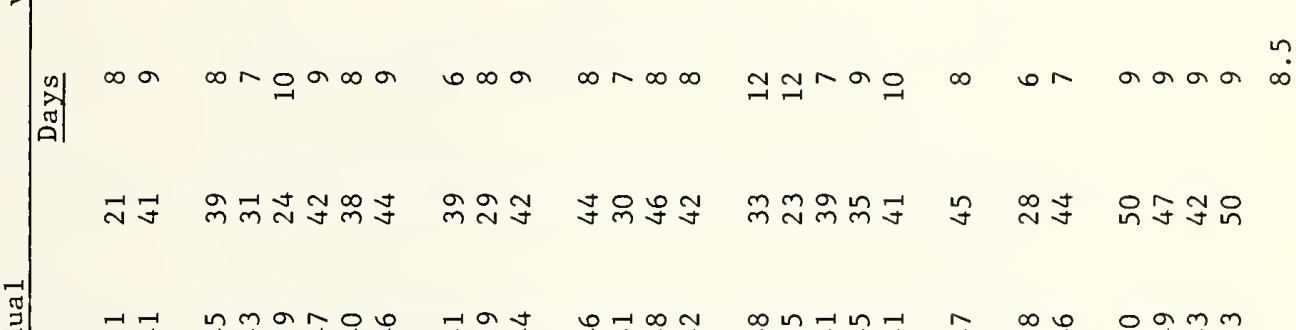 \\
\hline 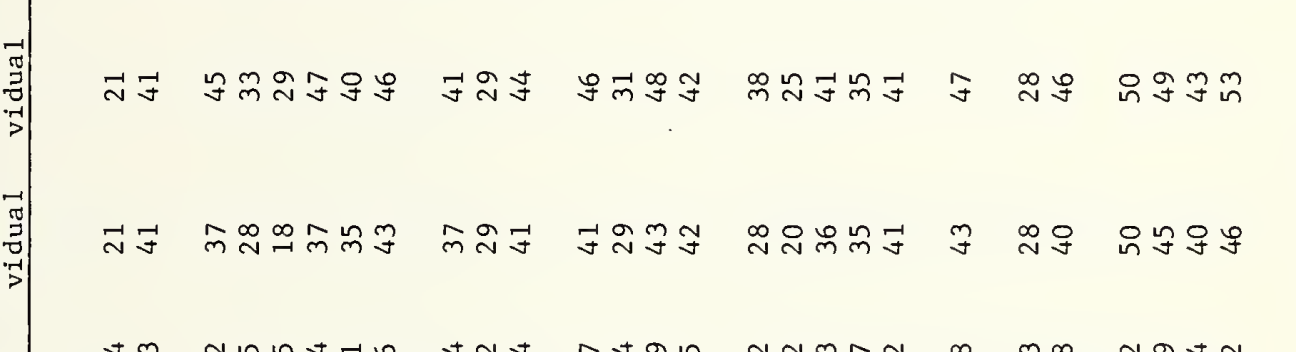 \\
\hline 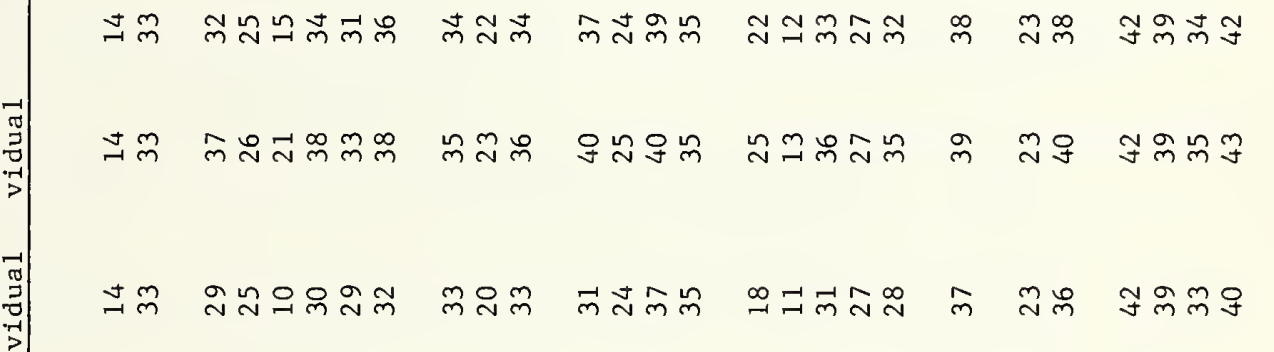 \\
\hline 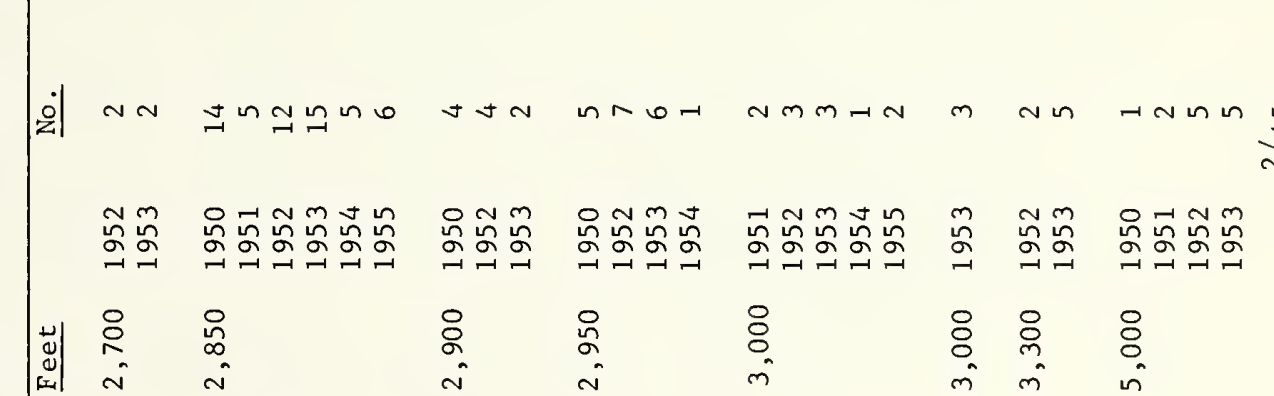 \\
\hline
\end{tabular}




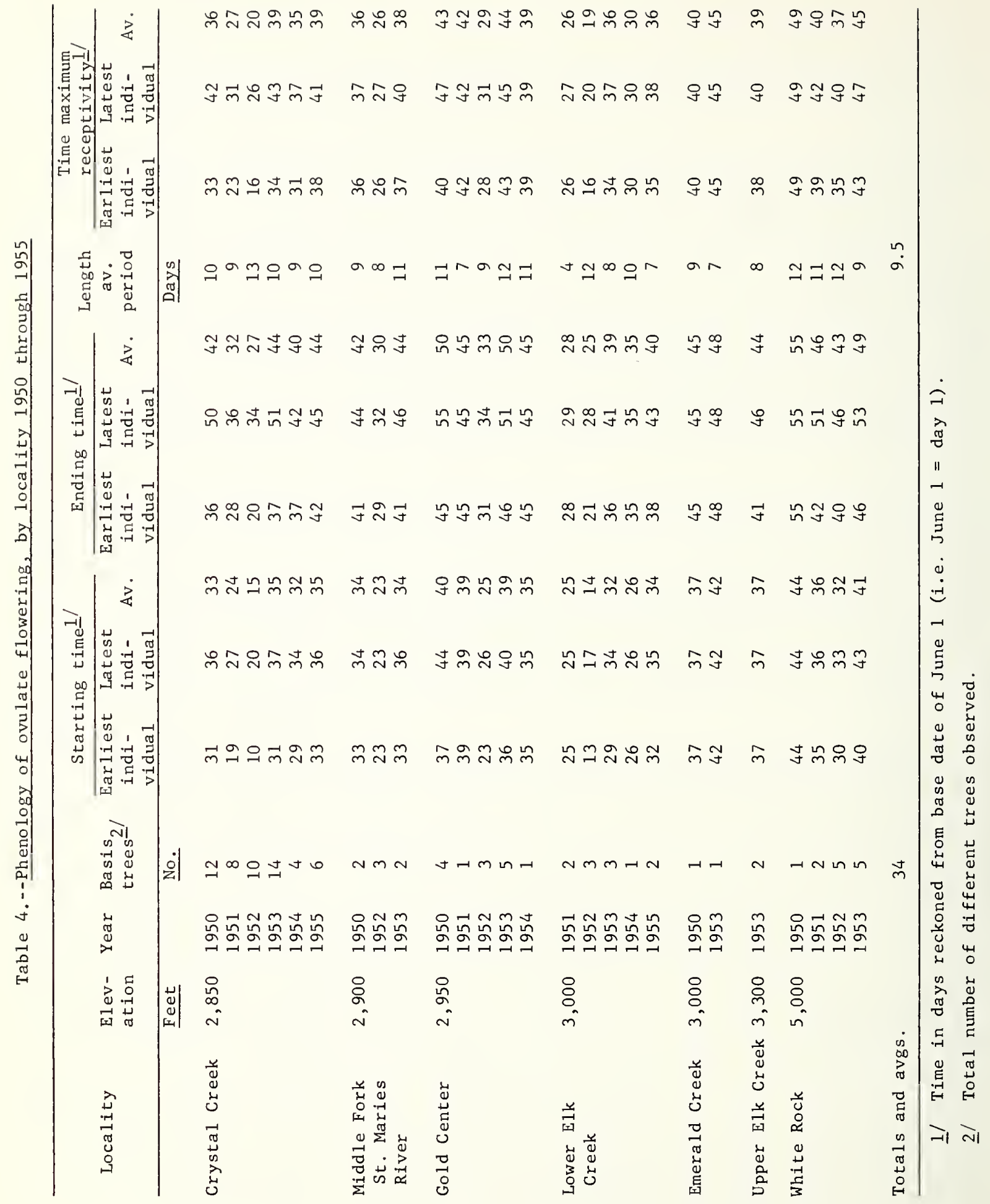




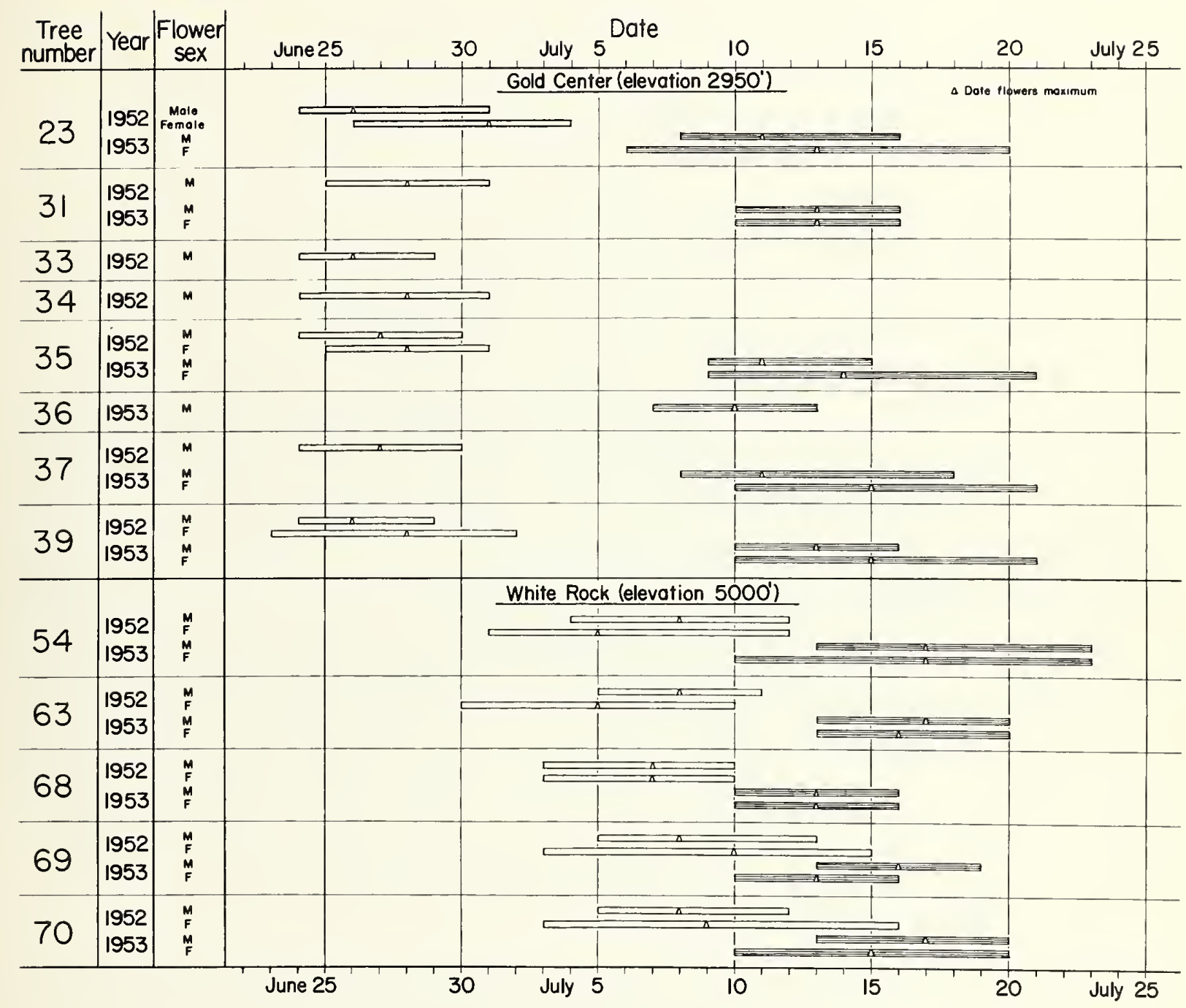

Figure 3.--Time, duration, and maxima of flowering of adjacent low and high elevation areas during an early (1952) and a late (1953) season. 
associated with earliness or lateness of individual seasons was telescoped more at the colder, high elevations than at the warmer, low elevations.

The range of latitude sampled in this study (only $1 / 3^{\circ}$ ) did not permit analysis to determine the effect of latitude on time of flowering of $\underline{P}$. monticola, but effects of latitude on the time of flowering of a number of other pines have been reported in the literature and are shown in table 1.

\section{Consistency in Sequence of Flowering}

The relative consistency in sequence of flowering of individuals of different species in the same locality has fascinated man since ancient times. It is one of the most completely documented phenomena concerning flowering of plants. The order of blooming in forest trees has also received considerable attention ( $1, \underline{44}, \underline{52}, \underline{42}, \underline{27}$, and table 1). Consistency in sequence of flowering of individual trees of one species in one locality, or in stands of one species at nearby localities, has received far less attention (table 1) and will be the subject of results and discussion that follow.

Certain individual $\underline{P}$. monticola trees were found to be consistently early or late in time of onset of flowering, in respect to other trees in the same locality. The sum of localized microclimatic or hereditary differences holding between different trees in the same locality seemed to have a similar net effect on time of flowering, year after year. Figure 2, plus the bulk of the phenological data plotted in the same manner but not shown, and table 5 serve to bring out this point. Figure 2 shows that the beginning of anthesis and female flowering in trees 25 and 58 occurred a few days earlier than in the average Crystal Creek tree; and that the onset of anthesis and female flowering in trees 24 and 27 occurred a few days later than in the average tree, while similar phenomena in trees 17 and 21 occurred nearer to the average date for the locality. Dates of first anthesis of the 6 trees, during the 6 years 1950 to 1955, were grouped for comparison in table 5. In the three seasons when trees 25 and 58 could be compared with trees 24 and 27 , the former pair commenced pollination 5 to 8 days sooner. Since the trees all lie at the same elevation and within one-half mile of each other on the same soil type, and since aspect, stand density, and other visible features of the site apparently were not associated with time of flowering, the authors concluded that the differences in flowering time were mostly heritable.

General observations of this sort have been reported for a number of species (table 1), but the more critical observations of Matthews (26) deserve special mention here. Matthews in making morphological investigations on 11 Larix leptolepis trees, all on flat ground in a 200-foot row, noted that despite envirommental uniformity certain of the trees were consistently different in respect to times of first pollen release, maximum pollen release, and first flower receptivity. Hereditary effects were indicated. 
Table 5.--Dates of first anthesis in phenologically early, average, or late blooming trees

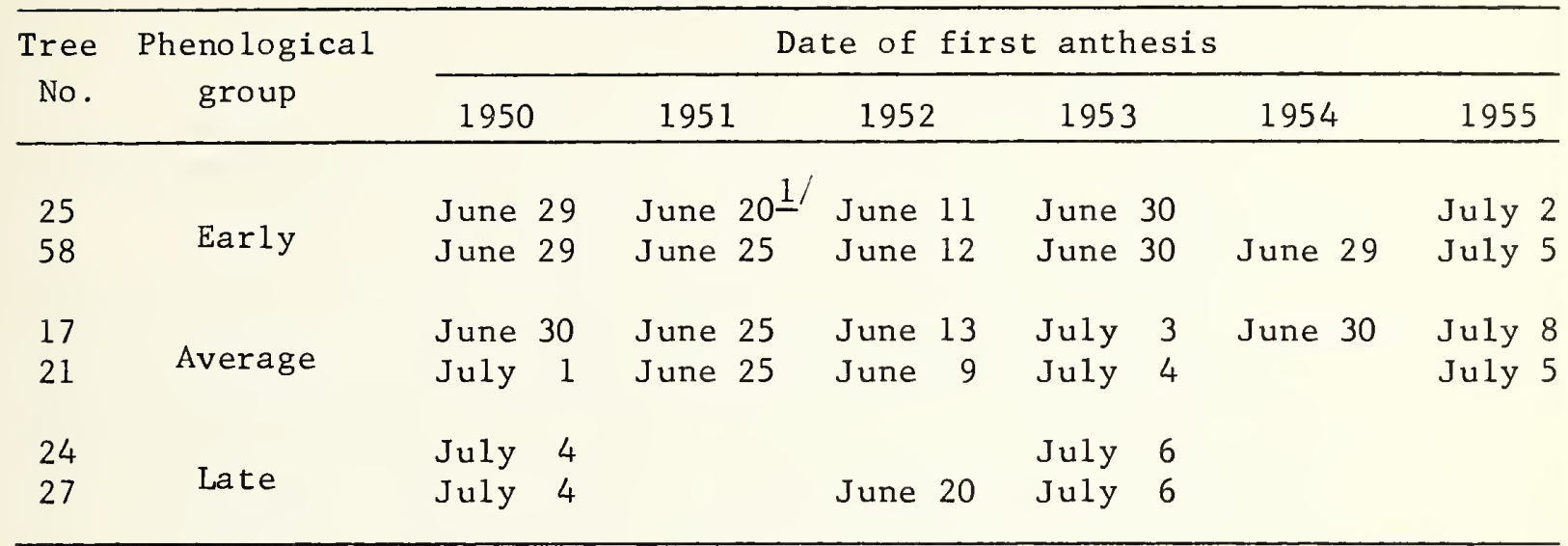
tuted.

1/ Bore only ovulate flowers in 1951; ovulate flowering date substi-

The sequence of flowering of $\underline{P}$. monticola at various localities within a small geographic area was even more firmly fixed. Table 6 shows the sequence in first anthesis at different localities, 1950 through 1955. During 6 years of observation in the 7 localities that lay in the elevational belt between 2,700 and 3,300 feet--Lower E1k Creek, Crystal Creek, Soldier Creek, Middle Fork of the St. Maries River, Upper Elk Creek, Emerald Creek, and Gold Center--the sequence of dates of first anthesis in these localities was in the order just given. It is difficult to appraise the effect of small elevational differences on time of flowering. Lower Elk Creek, for instance, was 300 feet higher than Soldier Creek and 150 feet higher than Crystal Creek, yet was always first in the relative order of flowering. Apparently within small elevational zones local microclimatic differences, other ecological variables, and heredity combined to exert a greater influence on flowering than did elevation.

\section{Year-to-Year Variation in the Time of Flowering}

In $\underline{P}$. monticola it was noted that within a given locality fairly great year-to-year variation occurred in time of staminate and ovulate flowering (tables 3 and 4). For instance, in Crystal Creek in the 6 years 1950 to 1955 average time of maximum pollination varied between June 19 and July 9 (i.e. between day number 19 and 39, reckoning day number from a June 1 base date). Over the same period maximum ovulate flower receptivity varied between June 20 and July 9. This amounted to a total variation of about 3 weeks in the 6 years. Annual variation in time of flowering of forest trees has been well documented (table 1) and is associated largely with differences in temperature caused by widespread annual climatic variation or with differences in latitude or altitude. 


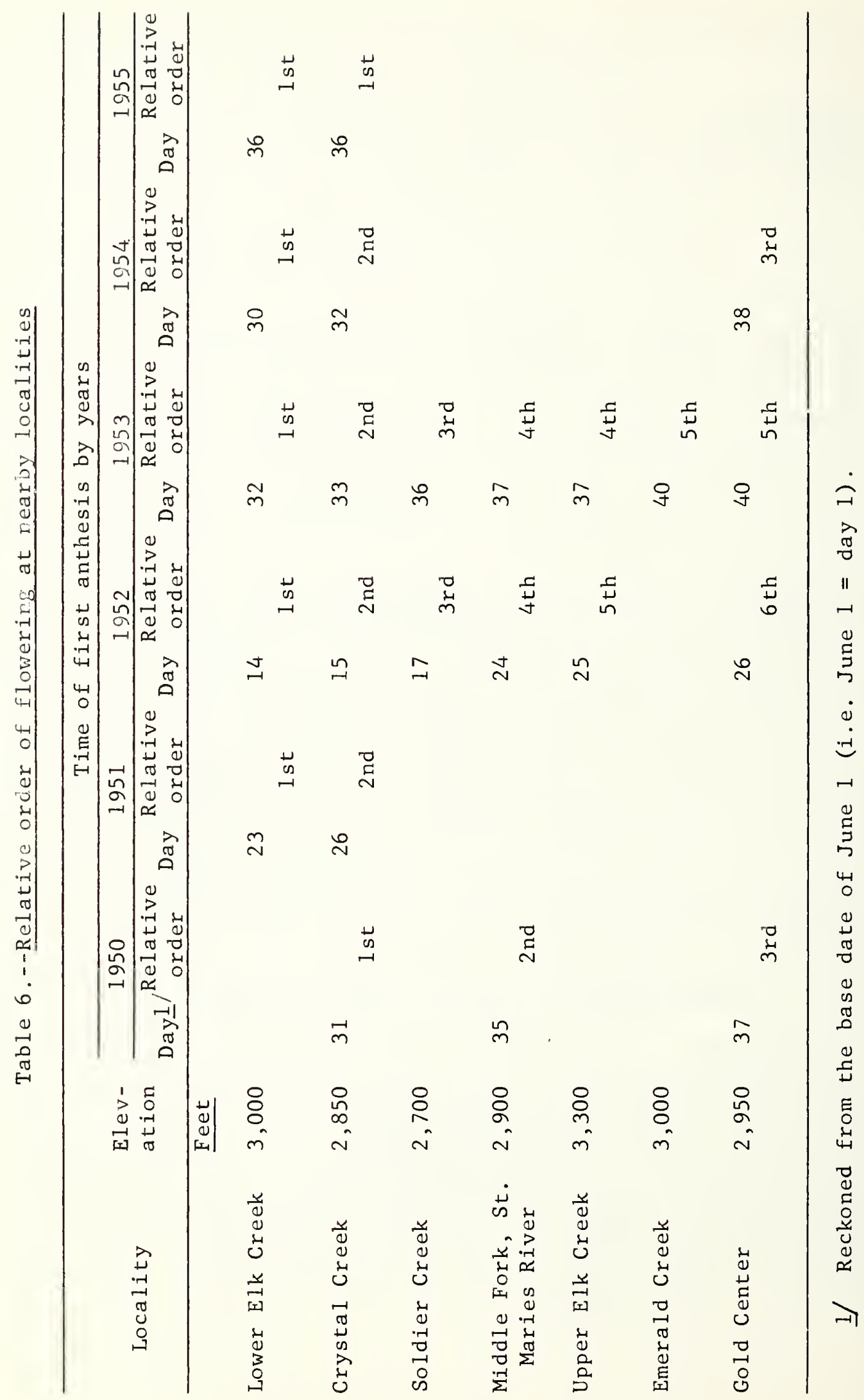


In P. monticola, as in many other species, time of flowering in a given year was found to be rather rigidly controlled by temperature of the several weeks immediately preceding flowering. Over 6 years, time of flowering within localities was highly and significantly correlated with average May and June temperatures, as shown in figure 4. The regression equation, $Y=20.3$ days 5.2 days $x \mathrm{X}$ degrees $\mathrm{F}$. (i.e. for each degree Fahrenheit that May and June temperatures departed from normal, time of flowering varied approximately 5 days) was calculated to express the relationship.

The meteorological aspects of the flowering time of trees in different seasons have been explored by Blendel (ㄱ) , Dancklemann (11), Osterwalder (34), Lindsey and Newman (25), Misic ( $\underline{30})$, and many others, by the method of heat summation. Temperature effects have also been appraised by Minsha11 (29), Duffield (14), Clapper (3), and Scamoni (39). All of these workers have shown that time of flowering was closely associated with temperature.

\section{Timing and Overlap of Periods of Staminate and Ovulate Flowering}

During the same season most individual trees within localities were remarkably similar in respect to times of pollen shedding and ovulate flower receptivity. Ordinarily, within a given area, departure of individual trees from the average date of first pollen shedding amounted to no more than 2 or 3 days, rarely more than 4 days. Similarly, all individuals within localities reached the time of first ovulate flower receptivity within a period of 1 or 2 days, rarely more than 3 days (fig. 2).

More important, within most individual trees and individual stands, times of maximum pollination and maximum ovulate flower receptivity were practically coincident, often occurring on the same date, but with maximum receptivity usually occurring about 1 or 2 days after maximum pollination (fig. 2, tables 3 and 4). From a phenological standpoint it appeared that the majority of trees were almost completely self-and cross-compatible.

In order to obtain a quantitative expression of phenological control over either selfing or crossing, the minimum and average numbers of days on which selfing or crossing was possible were computed for the trees in each locality (table 7). It was noteworthy that among 33 trees observed repeatedly through 2 to 6 seasons (on the average of 3 times per tree) not a single instance of complete dichogamy occurred. In individual trees having an average flowering period of $8 \frac{1}{2}$ to $9 \frac{1}{2}$ days (tables 3 and 4 ) the observed minimum overlap in periods of pollen shedding and ovulate flower receptivity was 3 days, the average overlap 7 days. Neither were there phenological barriers to crossing, the trees within a given locality being more or less completely crossable in a given season. Among 691 natural crosses that could have occurred within 8 localities in the years 1950 through 1955, in only one instance would a cross (or its reciprocal) have been impossible. Average number of days during which crossing could have taken place within areas was 6 days. 


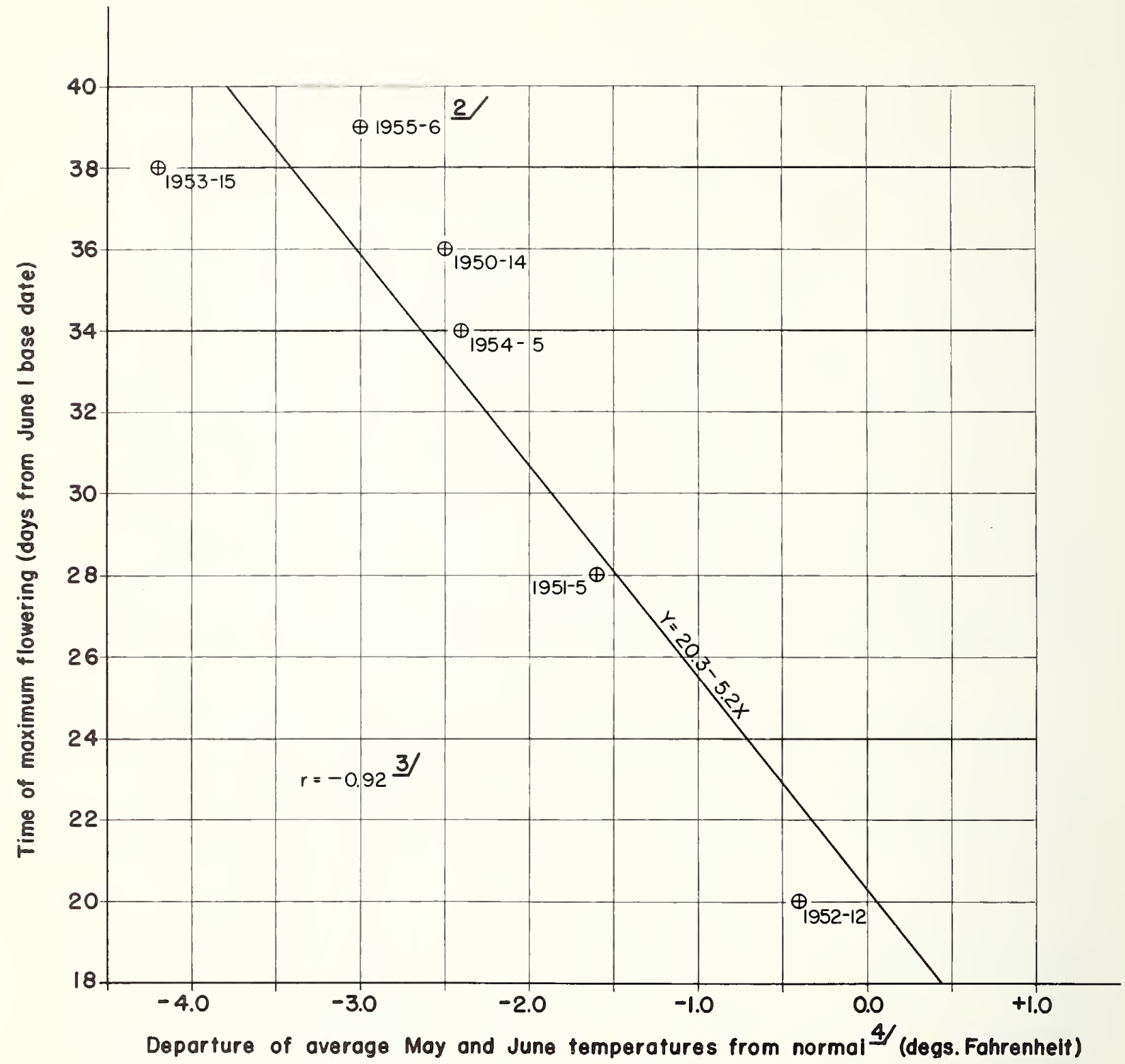

1/ Average of times of maximum staminate and ovulate flowering, Crystal Creek area.

2/ Year and number of trees observed.

3/ Correlation coefficient (r) significant at the 1-percent level of probability.

4/ Average of May and June departures published by the U. S. Weather Bureau, Northern Division, Idaho.

Figure 4.--Relation of spring temperature and time of flowering. 
Table 7.--Phenological controls on selfing and crossing, by locality 1950 through 1955

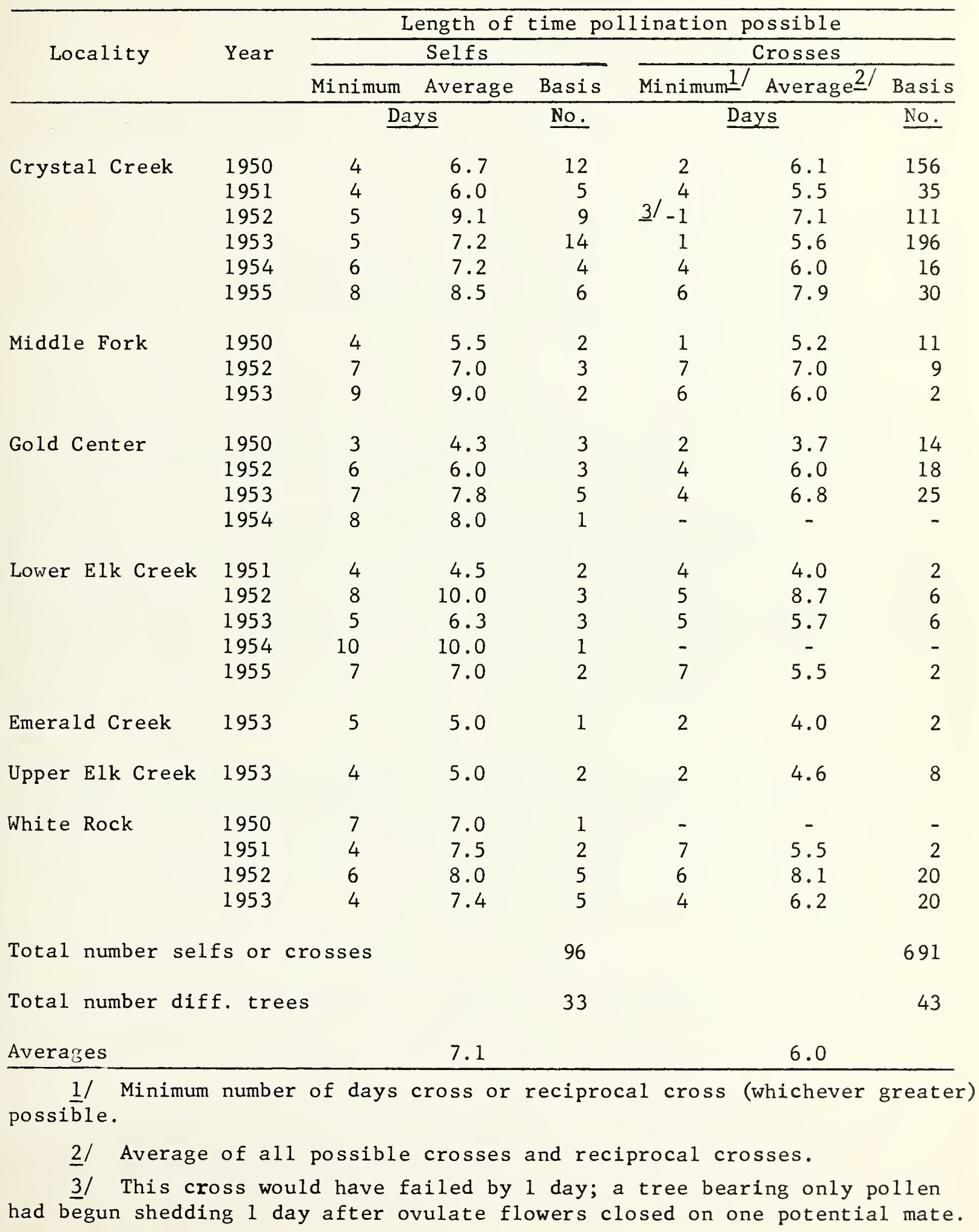


These data strengthen the conclusion of Bingham and Squillace (ㅁ) that no major phenological barriers to natural selfing occur in $\underline{P}$. monticola. While it is true that the large bulk of pollen is released during a relatively few days ( 36,37 , and 39 ) and that in some species a relatively small difference in timing of maximum pollination and ovulate flower receptivity conceivably could limit self-or cross-pollination, this is certainly not true for $\underline{P}$. monticola. The overlap in periods of male and female flowering for the average of 7 out of 9 days of the flowering season practically precludes the possibility that none of the ovulate flowers will attain naximum receptivity during the period of maximum pollen flight. Most pines, and for that matter most conifers, seem to be similar in this respect. Table 1 shows that most pines have been found synacmous, or at most only slightly protandrous or protogynous in flowering habit. Notable exceptions occur among introduced conifers--in Larix spp. (23,$\underline{24}$, and $\underline{26}$ ) and in Pinus mugo and $\underline{P}$. tabulaeformis (13)--but nothing was found regarding performance of these species in their natural habitats.

In hardwoods, notably nut trees of the genera Corylus, Castanea, Carya, and Juglans, sterility due to phenological differences in male and female flowering is well documented and deserves special mention $(\underline{2}, \underline{3}, \underline{8}, \underline{32}, \underline{41}$, $43,46,47$, and 49). Even so, while Vilkomerson (49), Clapper (3) and Nienstaedt (32) variously noted the existence of protandrous and protogynous individuals in Castanea, Nienstaedt stated that ample overlapping of flowering periods occurred and that dichogamy could not explain the pronounced selfincompatibility frequently observed for the genus. Similarly in pecans, where complete ranges of pollination and ovulate flower receptivity are given ( $\underline{3}$ and 43), overlapping of flowering periods is seen among certain varieties generally classified as dichogamous. Thus it would seem that in both pecans and chestnuts sterility is at least partly due to other than phenological barriers.

\section{CONCLUSIONS}

Duration of flowering in most pines, $\underline{P}$. monticola included, is probably somewhat longer than generally believed. Individual pines release measurable amounts of pollen for $\frac{1}{2}$ to 3 weeks, and stands of one species in one locality for 1 to 5 weeks. Onset of flowering is delayed by increasing altitude and latitude, the effects of latitude apparently being more pronounced in continents having "continental" vs. "oceanic" climates (table 1).

Consistent earliness or lateness in the flowering of individual $\underline{P}$. monticola trees has been noted. While this is important in timing controlled pollination work, it probably has little effect on the course of natural cross-pollination. Relative order of blooming is strongly fixed by locality and may have some significance in evolution of ecotypes.

Year-to-year variation in time of onset of flowering in pines ranges up to $2 \frac{1}{2}$ months, varying with the species and the number of years of observation. Six years' observations of $\underline{P}$ : monticola produced about 3 weeks' variation in time of flowering, and as with most pines this variation was strongly associated with spring temperatures. 
The belief that pines are generally dichogamous has little basis in fact. In most instances where flowering of individuals or stands of one species has been more than casually observed, pines have been found to be synacmous in flowering habit, or at most only slightly protandrous or protogynous. In $\underline{P}$. monticola stands, and apparently in stands of most other pines, little if any phenological cross-sterility could exist. Selfsterility, where occurring, will have to be explained on the basis of barriers other than phenological.

\section{SUMMARY}

In 45 young Pinus monticola trees where flowering was closely observed for periods up to 6 years, the following results were obtained:

(1) Average dates of first anthesis at low and high elevations for the species $(3,000$ and 5,000 feet) were June 27 and July 8, respectively.

(2) The period of pollen dissemination in stands at eight localities averaged $8 \frac{1}{2}$ days, the period of ovulate flower receptivity $9 \frac{1}{2}$ days.

(3) Very fruitful individuals, due to successive ripening of ovulate flowers, had prolonged flowering periods.

(4) Flowering was delayed about 5 days per 1,000 feet increase in elevation, about 6 days per degree F. departure of May and June temperatures below normal.

(5) At high elevations differences in date of onset of flowering in "early" vs. "late" seasons were smaller than at low elevations.

(6) Certain individual trees were found to be consistently a few days "early" or "late" in time of onset of flowering, in respect to other trees in the same locality. Sequence of flowering between localities was found to be very firmly fixed.

(7) Time of onset of flowering varied over a period of 20 days during 6 years of observations.

(8) Time of flowering in a given year was rigidly controlled by temperature of the several weeks immediately preceding flowering.

(9) Within individual trees and within localities, maxima of pollen shedding and ovulate flowering were for practical purposes coincident. No phenological barriers to either selfing or crossing were found to exist in the 45 trees tested.

(10) Many of the above findings hold equally well for many of the other pines. 


\section{LITERATURE CITED}

(1) Anonymous

1955. 2nd Northeastern Forest Tree Improvement Conference Proceedings, 1954. $68 \mathrm{pp}$.

(2) Adriance, Guy W.

1930. Dichogamy in the pecan. Amer. Soc. Hort. Sci. Proc. 1930: 435-439.

(3)

1931. Factors influencing fruit setting in the pecan. Bot. Gaz. $91(2): 144-165$.

(4) Anderson, Edgar, and Hubricht, Leslie

1940. A method for describing and comparing blooming seasons. Torrey Bot. Slub. Bul. $57(8): 639-648$.

(5) Bingham, R. T., and Squillace, A. E.

1955. Self-compatibility and effects of self-fertility in western white pine. Forest Sci. 1(2): 121-129.

(6) Bingham, R. T., Squillace, A. E., and Duffield, J. W.

1953. Breeling blister-rust-resistant western white pine. Jour. Forestry 51(3): 163-168.

(7) Blende1, Frederick

1887. Flora Peoriana: The vegetation in the climate of middle Illinois. 89 pp. Peoria.

(8) Clapper, Russell B.

1954. Chestnut breeding, technique and results. I. Breeding material and pollination techniques. Jour. Heredity 45(3): 107-114. II. Inheritance of characters, breeding for vigor, and mutations. Jour. Heredity 45(4): 201-208.

(9) Criddle, N. A.

1927. A calendar of flowers. Canad. Field-Naturalist 41: 48-55.

(10) Cumming, W. C., and Righter, F. I.

1948. Methods used to control pollination of pines in the Sierra Nevada of California. U. S. Dept. Agr. Cir. 792, 18 pp.

(11) Danckelmann, B.

1898. Phănologie der Holzarten im deutschen Walde. Zeitschr. f. Forst-u. Jagdw. $30(5)$ : 263-290.

(12) Dorman, Keith W., and Barber, John C.

1956. Time of flowering and seed ripening in southern pines.

Southeast. Forest Expt. Sta., Station Paper 72, 15 pp. 
(13) Doyle, Joseph, and O'Leary, Mary

1935. Pollination in Pinus. Sci. Proc. Roy. Dublin Soc. 21(20): 181-190.

(14) Duffield, J.W.

1953. Pine pollen collection dates--annual and geographic variation. Calif. Forest Expt. Sta., Forest Res. Note 85, 9 pp.

(15) Ehrenberg, Carin Eklundh, and Simak, Milan

1956. Flowering and pollination in Scots pine (Pinus silvestris L.) Meddel. fran Statens Skogsforskningsinst. 46 (12): 1-27.

(16) Fielding, J. M.

1947. The seeding and natural regeneration of Monterey pine in South Australia. Austral. For. and Timber Bur. Bul. 29, 60 pp.

(17) Garner, W. W.

1937. Recent work on photoperiodism. Bot. Rev. 3: 259-275.

(18) Holman, Richard M., and Robbins, Wilfred W.

1934. Life history of Pinus, pp. 522-539 in, A textbook of general botany for colleges and universities. Ed. 3, xv. $626 \mathrm{pp}$. New York.

(19) Hopkins, A. D.

1918. Periodical events and natural law as guides to agricultural research and practice. U. S. Dept. Agr. Mo. Weather Rev., Supp1. 9: 1-42.

(20) Huberman, M. A.

1941. Why phenology? Jour. Forestry 39(12): 1007-1013.

(21)

1943. Phenology in forestry. Chronica Botanica 7(8): 403-404.

(22) Lamb, George N.

1915. A calendar of the leafing, flowering, and seeding of the common trees of the eastern United States. U. S. Dept. Agr. Mo. Weather Rev., Supp1. 2: 5-19.

(23) Leven, J. K.

1949. Some experiments in the cross pollination of European and Japanese larch. Quart. Jour. For. 43(2): 57-66.

(24)

1951. Flowering times of Japanese larch (L. Leptolepis Murray) and European larch (L. europea D.C.). Scot Forestry 5(2): 33-44.

(25) Lindsey, Alton A, and Newman, James E.

1956. Use of official weather data in sprin time--Temperature analysis of an Indiana phenological record. Ecol. 37(4): 812-823. 
(26) Matthews, J. D.

1954. Japanese larches at Dunkeld, Perthshire; a study in variation.

Gr. Brit. For. Comm. Forest Record 25, 23 pp.

(27) Meehan, S. M.

(n.d.) Flowering times, the expected dates when trees and shrubs will bloom in the Philadelphia area. E11is Coll. Arb. pub., 8 Pp.

(28) Millett, M. R. O.

1944. Pollen shed in Monterey pine. Austral. Commonwealth For. Bur. Leaflet $59,8 \mathrm{pp}$.

(29) Minsha11, W. H.

1947. First days of anthesis for four trees at Ottawa, Ontario for period 1936 to 1945. Canad. Field-Naturalist 61(2): 5659.

(30) Misic, P. D.

1956. The effect of meteorological factors upon the beginning of flowering of certain apple tree varieties. Arh. za Poljoprivredne Nauke 9(23): 37-48.

(31) Munns, E. N.

1938. The distribution of the important forest trees of the United States. U. S. Dept. Agr. Misc. Pub. 287, 176 pp.

(32) Nienstaedt, Hans

1956. Receptivity of the pistillate flowers and pollen germination tests in genus Castanea. Zeitschr. f. Forstgen. u. Forstpflanzenzüch. 5(2) : 40-45.

(33) Orr-Ewing, A. L.

1956. Controlled pollination techniques for the Douglas fir. Forest Sci. $2(4)$ : 251-257.

(34) Osterwalder, A.

1949. Die Warmeansprüche unserer Obstfrücht und Traube von der Blute bis zum Reife. Landwirtschlaftliches Jahrbuch der Schweiz $63(7): 687-718$.

(35) Roeser, J., Jr.

1941. Some aspects of flower and cone production in ponderosa pine. Jour. Forestry $39(6)$ : 534-536.

(36) Sarvas, Risto

1952. On the flowering of birch and the quality of seed crop.

Commun. Inst. Forestalis Fenniae $40(7):$ 1-38. 
(37) Sarvas, Risto

1955. Investigations into the flowering and seed quality of forest trees. Commun. Inst. Forestalis Fenniae 45(7): 1-37.

(38) Scamoni, A.

1938. Über eintritt und Verlauf der Männlichen Kiefernblute.

Zeitschr. f. Forst-u. Jagdw. $70(6): 289-315$.

(39)

1955. Beobachtungen über den Pollenflug der Waldbäume in Eberswalde. Zeitschr. f. Forstgen. u. forstpflanzenzüch. 4(4/5): 113122 .

(40) Scepotjev, F. L.

1954. O raznokačestvennosti cvetkov v krone grekogo oreha (Juglans regia L.). Akad. Nauk SSSR. Dok. 96(1): 197-200. (Seen only as abstracted in For. Absts. 16(3): No. 2774.)

(41) Schuster, C. E.

1927. Sterility in filberts. Mem. Hort. Soc. N.Y. 3: 201-211.

(42) Silker, T. H.

1956. Hardwood phenology in southeast Texas. Tex. For. Serv. Res. Note 15,4 pp.

(43) Smith, C. L., and Romberg, L. D.

1940. Stigma receptivity and pollen shedding in some pecan varieties. Jour. Agr. Res. $60(8)$ : 551-564.

(44) Smith, J. Warren

1915. Phenological dates, etc., recorded by T. Mikesell at Wauseon, Ohio. U. S. Dept. Agr. Mo. Weather Rev., Supp1. 2, 71 pp.

(45) Snow, A. G. Jr., Dorman, K. W., and Schopmeyer, C. S.

1943. Developmental stages of female strobili in slash pine. Jour. Forestry 41(12): 922-923.

(46) Stout, A. B.

1928. Dichogamy in flowering plants. Torrey Bot. Club. Bul. 55(3): 141-153.

(47) Stuckey, H. P.

1916. The two groups of varieties of Hicoria pecan and their relation to self-sterility. Ga. Agr. Expt. Sta. Bul. 124: 127-148.

(48) Tiurin, A. V.

1956. The course of blooming of Scotch pine in European SSSR. In Russian) Bot. Zhur. 41: 568-571. 
(49) Vilkomerson, Hilda

1938. The flowering habits of chestnuts with special reference to self-fruitlessness. M.S. essay (Botany), Columbia Univ. $32 \mathrm{pp}$.

(50) Wright, Jonathan W.

1952. Pollen dispersion of some forest trees. Northeast. Forest Expt. Sta., Station Paper 46, 42 pp.

(51)

1953. Notes on flowering and fruiting of northeastern trees. Northeast. Forest Expt. Sta., Station Paper 60, 38 pp.

(52) Wyman, Donald

1950. Order of bloom. Arnoldia 10(7/8): 41-56.

(53) Zobel, Bruce J and Goddard, Ray E.

1954. Pine flowering and seed ripening in Texas. Tex. For. Serv. Res. Note 8, 10 pp. 


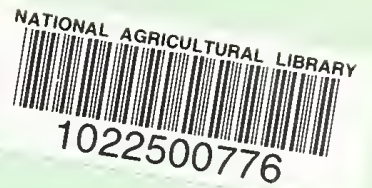


NATIONAL AGRICULTURAL LIBRAR

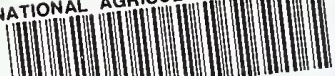

1022500776 